\title{
Dictates by the International Capitalism. Who Governs?
}

\author{
Noralv Veggeland \\ Professor of Public Policy, Inland Norway University of Applied Sciences, \\ Lillehammer, Elverum, Norway
}

Doi: 10.19044/esj.2018.v14n4p30 URL:http://dx.doi.org/10.19044/esj.2018.v14n4p30

\begin{abstract}
The representative democracy has become weak and fragmented, and under control of international market policy approaches of national state governments and multilateral agreement organizations like the European Union. In this paper, I argue that any study and explanation of economic crises and their contemporary supranational governance structures solutions conducted in the democratic capitalism countries as USA during the last fifty years, must be anchored in a multidisciplinary context. Crises of the art are rooted in social structures and classes, and in the behavior of the capitalistic system, based on inequality and new classical economic theory and right-wing political ideology.
\end{abstract}

Keywords: Financial crisis. Recession, Western capitalism, European integration, fundamental mechanisms of the capitalistic system

\section{Introduction}

The political German scientist Wolfgang Streeck writes in the Le Monde Diplomatique, January 2012 that "Every day we read in the newspapers that the markets dictate what sovereign and democratic states can do and what they cannot do for their citizens. The consequence is that the citizens not any longer look upon their government as their representatives but as representatives for interest of foreign states and international organizations." This is a correct statement. However, one term should be substituted with another one. It is not the market that directly dictates governments - that is what deregulation of markets does. There is a close relation between the development of the modern western regulatory state and the process of creating markets and correcting markets in terms of Giandomenico Majone's conceptualization of the regulatory state (Majone, $1994 ; 1997 ; 2003)$. It is regulations to accomplish these goals - both nationally and internationally - which dictate governments. The European Union dictates 
the government of the member states. So does membership of the World Trade Organization (WTO); national impotence is the outcome of the huge amount of worldwide market agreements.

Financial crisis and recession dominate the Western capitalism of our time. The crisis in the Euro-zone is evidently a grave blow to European integration, but is intimately connected to the international financial crisis. The collapse of the national state finances may be understood as a manifestation of a fundamental mechanism in the capitalistic system, where un-balance and un-stability are the rule instead of the opposite. After the Second World War, western democratic capitalism went through three successive and conflicting phases, and is now going through a forth one.

In Europe, where the financial crisis transformed into sovereign debt crises in several countries, the current phase of the denial cycle is marked by an official policy approach predicated on the assumption that normal growth can be restored through a mix of austerity, privatization and less state involvement (anti-Keynes). The claim is that advanced countries do not need to apply the standard toolkit used by emerging markets, including debt restructurings, higher inflation, capital controls, and significant financial repression. Advanced countries do not resort to such gimmicks, policymakers say. To do so would be to give up hard-earned credibility, thereby destabilizing expectations and throwing the economy into a future vicious circle. Although the view that advanced country financial crises are completely different - and therefore should be handled completely differently - has been a recurrent ideological refrain (notably in the European sovereign debt crises and the U.S. subprime mortgage crisis), this view is at odds with the historical track record. In most advanced economies, based on Keynesianism, state intervention, debt restructuring or conversions, financial tools, and higher inflation have been integral parts of the resolution of significant debt overhangs.

The post-war period of economic crises started with phase one - the stagflation crisis of the 1970s. Afterwards came phase two - a public deficit crisis, followed by phase three - a privatized deficit crisis. Today, the forth phase is at work, consisting of both a public and a privatized deficit crisis - a combination crisis. Adequately, three solutions to crises has been tested out with conditional success, and a forth solution is by now implemented. What we know is that every one of the solutions for the crises using traditional tools has led up to a yet another crisis.

\section{The Stagflation crisis}

The so called stagflation crisis emerged in the 1970s. Globalization, deindustrialization, and lowered economic growth generated both unemployment and inflation as parallel processes, thereof the term Stagflation 
(stagnation and inflation) crisis. According to Keynesian interventionist economic theory two such parallel processes should not happen. The democratic capitalism was in a deep crisis, followed by strikes and riots from students and the working class. The Governments sought their solution by leaning their shoulders to an expanding monetary economy. To regain peace between labor and capital the government at the time left the Keynesian welfare state policy in order to secure money for investments in industries and workplaces. However, at the same time the welfare state was expanded and social security schemes were erected, and salaries for the workers were increased. In the beginning, the inflation was not a real problem for the working class. The working class was organized in strong trade unions, which were able to assure salaries were adjusted according to the inflation. Inflation bothers and threatens first and foremost creditors and people owning bank accounts, and not owners of real estate and those involved with speculation of capital. The working class is normally not a part of the two latter. Streeck (2012) writes that there are reasons to believe that the inflation at the time may be looked upon as a monetary political reflex of a conflict of allocation between a labor force who claim access to work and a greater share of the national income, and a speculative class of capitalists whose intention was to maximize the profit of the capital. In this context inflation means an economic situation out of control; the working class claims welfare state rights while the capitalists stress the rules of the market and the holy right of private selfgovernance.

The stagflation crisis hit the relation and balance between labor and capital, and thereof the traditional democratic principles. A democratic deficit was the result, and led to politics of fighting the inflation by national and international regulation. The politics became subordinated judicial decisionmaking (Europautredningen 2012). As a general phenomenon in the regulatory state, the term democratic deficit indicates that elected and representative assemblies at different levels have become politically weakened, while technocratic implementing authorities of regulations have strengthened their power because they have been given independent selfregulatory power by law. The law might be national public law, international law or private corporation statutes (Veggeland 2010, 2012).

This represents - as already mentioned - a dilemma, as far as it concerns the democratic order. Laws, agreements and regulations start dictating national policies; governance replaces government. The citizens don't look upon their governments as their own representatives but as representatives for other independent powers outside their domain. The weakening of the representatives creates a deficit of parliamentary democracy, it means a deficit of 'government by the people', causing the upcoming of 'governance for the people (Scharpf 1999). Steering and service producing 
groups of regulators, arm's length bodies, networking groups, partnerships, provide governance for the people, and replace representative political government and ordinary public administration. Michael Keating (1998:39) expresses the situation this way: 'governance is what exists when government is weak and fragmented.'

The new democracy that occurred after the stagflation crisis is split into two institutional principles, i.e. first what is called an input government democratic order, and second, an output governance democratic order like the US and the EU. The input democratic order gets its legitimacy from its parliamentary chain, while the output democratic order gets its legitimacy from its ability to accomplish efficiency and results related to set-ups of political goals. 'In the regulatory state, policies gain their legitimacy first and foremost from achievements, efficiency, and effectiveness, that is, from the output or outcome of agencies and executives' (Lane and Ersson, 2003: 183).

Let us go back and look closer upon the Keynesian principles, including the principles of an active interventionist state which was responsible for balancing the relation between inflation and unemployment.

\section{Increasing inflation}

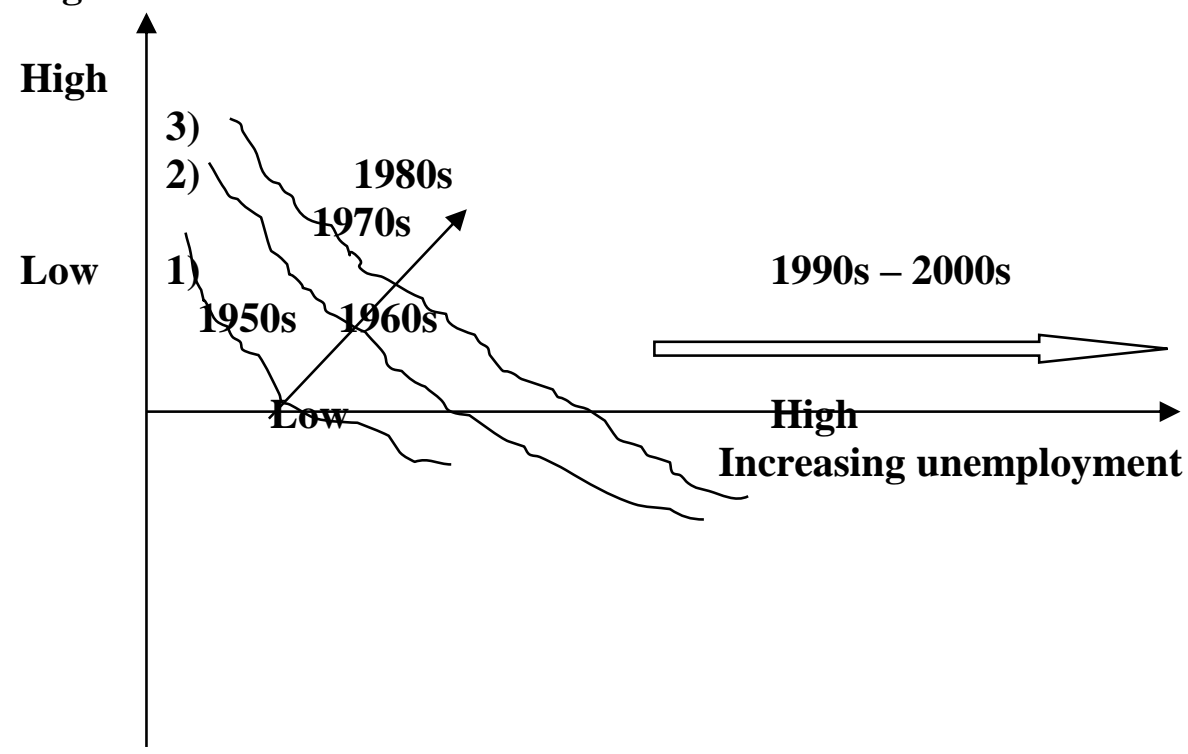

Figure 1: The Phillips-curve: The original curve shows the empirical relation between inflation and unemployment. The thin arrow indicates a development coming up in 1970s and 1980s with both increasing inflation and unemployment through the years. The thick arrow indicates the present low inflation but growing unemployment through the 1990s and 2000s.

The characteristics of the Phillips-curve were drawn by the economist W. Phillips in 1958, based on empirical evidence. Marked 1) in fig. 1 the 
original curve is presented showing the relation between inflation and unemployment in national economies in the 1950s. In the Keynesian welfare state, it was the responsibility of the state to secure balance at a low level for both inflation and unemployment. With increasing inflation, the state was organized to reduce the effective demand and thereby increase the unemployment, and the other way around with increasing unemployment - the state should intervene financially and stimulate the effective demand. In the 1950s and 1960s this mechanism functioned with stable inflation and unemployment at a low level.

In the 1970s the Keynesian mechanisms finished working as they used to do; as fig. 1 illustrates, the curve started moving upwards. The national economies in the OECD-countries stabilized on higher levels both regarding inflation and unemployment (OECD 1997), see fig. 1. The inflation crisis had emerged.

The leading economists were quite confused and the OECD hesitated regarding counteracting advices to their member states. In the 1980s came the advice at last - priority should be given to fighting the inflation growth. Low inflation should again be reestablished with the consequence of increasing unemployment. This decision was in accordance with the wave of theories introduced by the Nobel Prize Winner Milton Friedman (1962/1972: 39), which stressed monetary principles, i.e. regulatory politics controlling the amount of money circulating in the economy, and the establishment of an objective for inflation stabilization at a low level. Friedman writes: "There is a widespread recognition that control over money can be a potent tool for controlling and shaping the economy" (1972:16). This power to control and to manage the economy he excluded from the governments and transferred to the financial institutions. In the wake of his theory, the national central banks became organized as arm's length bodies, with the disappearing of political instruction authority. The central banks were given the authority to manage the monetary politics, such as to decide the level of the interest rate and to control the currency value in relation to other countries' currency values.

The term used to characterize the ruling monetary politics was supplyside economy. This politics was based ideologically on liberalization ideas regarding credit policies. Fig. 1 marks the development by the thick arrow indicating low inflation rate but growing unemployment as a consequence. The politics represented a temporary solution to the stagflation crisis, but at the same time, little by little, created the conditions for a new crisis development - the public credit crisis described below. Monetary economic policy established the new regulatory state (Veggeland 2010), together with globalization processes and the development of transnational networks constituted problems, which needed regulation to be temporarily solved. The removal of political instruction authority in the wake of New Public 
Management (NPM) theories and practice (Lane and Ersson 2003) generated in its prolonging of governance the democratic deficit. Monetary regulation and regulation in general - worked fine from its onset, achieving goals of liberalism and thereby legitimacy, i.e. output legitimacy. The output legitimacy challenged the traditional principles of parliamentary democracy, i.e. the input representative democracy.

The new democracy of the regulatory state and the democratic capitalism inhere both dependent and independent variables (Dahl, 1989). The input democratic side, together with the regulatory function of the constitution, represent the parliamentary democracy. However, the input elements of steering depend intimately on how the regulatory authorities are organized on the output side of the democracy. Michael Keating (1998) suggests that regulatory regimes are what expand when the input democracy is weak and fragmented. He indicates that regulatory regimes threaten the traditional democratic order. The statement is not obviously true. It might be that what concerns him is the balance between work and capital. The weakening of the trade unions as part of the input democratic order means that the market and the capital gain output democratic power. That is what happened in the wake of the stagflation crisis. The regulatory state penetrated the representative democratic order leaving it weak, and the citizens in a state of political exclusion.

The European Union had to fundamentally continue to be rooted in a democratic order based on outcome legitimacy because of the Union's transnational character as a con-federal organization inhering supranational federal elements. This reality influences the member countries of the whole European Economic Area (EEA) (Europautredningen 2012) regarding steering ability. Joseph $\mathrm{H}$. Weiler, among others, points out in his book The Constitution of Europe, that a paradox occurs in this context. The EU's way of governance inheres a form of "dualism," concerning the representative and the outcome-based democratic order, he writes. According to Weiler this will also, in the long run, become the case because the EU suffers from a 'demos problem,' i.e. a loss of a coherent people, which means alien citizens neglecting the input democratic order and causing a weak parliamentary steering chain. The EU consists of numerous peoples with different languages, identities and cultures, with the non-existence of a single European identity. This indicates that a united input democratic federal Europe is unlikely to come into existence. The dualism has a structural explanation, supported by other conditional elements. Globalization and transnational networks connected to regulatory agreements maintain the dualism of the regulatory state (Scharpf 1999, Veggeland 2009). It started with the stagflation crisis in Europe, which generated ever more supranational power since the 1980s. 
The national markets for investments and consuming were too limited, and the integration of markets in Europe went on with the introduction of the internal market between $1988-1992$. New digital technology influenced the market integration. This technology created branches of growth and the raise of prices on both labor and capital. On the other hand, traditional branches stagnated. The outcome was stagnation and inflation as parallel processes, therefore - "stagflation" (Cumes, 1984). This happened in contrast to Keynesian theory which recommended an active and intervening state. According to this theory the state was obliged to intervene financially in the market in order to achieve political objectives. When unemployment increased, the state should have increased its investments in job creating activities, and the opposite when raising inflation. As fig. 1 indicates, the Keynesian theoretical tools did not work out effectively any longer. It became important to find a new path out of the crisis. Fighting inflation became the keyword for a solution. To achieve this goal of lowering the inflation, another goal came up, namely to eliminate the power of the national trade unions to make them ineffective in their struggle and claim for higher salaries.

New markets had to be created. A strategy was to market-orientate the public sector to make this sector contribute to the growth of the aggregating national income. Arm's length bodies organized in accordance with private sector's bodies, and steering by objectives became the ruling governance principle. The new regulatory state came into being, legitimized by the ideology of the new liberalism which claimed the economic perfection of market competition, steering by objections and open up new markets by the establishment of free trade zones and international agreements. Latest, the negotiation between the EU and USA goes on with the objective of establishing a huge free trade zone, TTIP between the two continents,

\section{The public crisis of credit}

Following the stagflation crisis, the adoption of extensive state loans happened in Western welfare states to compensate for inflation and stagnation, i.e. to get the inflation under control at a stable low level. However, the reasons for the fast growing public deficit were others, too. Stagnation and high unemployment made both rich and poor people skeptical towards tax payment, and new liberal politics for tax cuts got introduced in many Western countries, especially in Angle-Saxon countries like the USA and the UK. Either way, automatically, without inflation it became impossible to increase the taxes, simply because the salaries stagnated and often decreased, and this caused shrinking access for the state to tax revenues. The low economic growth also terminated the depreciation of public deficit along with the sinking of national currency values. This depreciation had been a supplement to economic growth 
because the inflation reduced the value of the credit deficit. Public loans were also necessary to maintain the services of the welfare state.

The inflation got under control in the late 1980s, though the unemployment rate stayed high in most Western countries. The high unemployment threatened the peace established in the labor market in the Western democratic countries, and thereof political support to the ruling political parties was undermined. Right wing parties/groups succeeded in their agitation for free market solutions. To increase the public deficit seemed to be the appropriate alternative solution to both the economic and political development problems. In short, the public loans arose heavily in countries like the USA and many of the EU member states. But similar to the inflation problem the national states can't increase their budget deficit indefinitely.

The economists pointed out the fact that financing public and private consuming by loan removed means for investment in the private sector. It would create an upheaval of the interest rate, and thereof a declining growth in that sector. The temporary solution to this negative situation and the first public economic deficit crisis, in accordance with ruling neoliberal ideology, was to liberalize the corporate financial sector. This approach started with organizational liberalization of Central Banks in many countries during the 1980s. An upheaval for lending money to people came into being, and minimal claims adhered to guarantee and security for loans to both private and public lenders were introduced. Stable low interest rate tempted the citizens to raise loans for both private consume and investments of high risk.

\section{The privatized crisis of credit}

Of course, the liberalization initiative did not mean that the governments had found an ultimate solution to the public credit crisis. However, the liberalized loan market generated new possibilities, namely access for most people to take advantage of the financial capital that was offered to them. Low interest rate decided by the central bank became a tool for keeping the level of consume high. Subprime loan taken up for consume became a substitute for a situation of stagnated welfare state policies. Banks and individuals believed in an enduring price upheaval in the real estate market. The value of a real estate unit was estimated to the price of $\mathrm{X}$, and loan was taken up according to that price with no other guarantee than the real estate itself. It was suggested that the next year the real estate could be sold for a price of $\mathrm{X}+\mathrm{Y}$, and from that transaction both the bank and individual loan taker was secured from loss of their invested money. Streeck calls this type of transaction thinking 'privatized Keynesianism' (Le Monde Diplomatique, January 2012), i.e. investment financed by loan in the private sector. Bubbles were created and later on burst. That was the situation in the 
USA in 2008 when the financial crisis became a reality. US economy became better off by 2015 in terms growth, but social inequality is increasing.

The economist Raghuram G. Rajan emphasizes the cultural aspect of the financial crisis, and figures out what he call 'Fault Lines' (2010). He points out powerlessness and the absence of coherence in the US democratic capitalism. In particular, in his explanation he emphasizes the catastrophic development of economic and social inequality occurring as a crisis in many Western countries, and with the USA as a leading nation in that sense. I have mentioned the risky behavior of the banks and heavy private loan taking leading to the financial crisis, and Rajan connects this development to the situation in the USA. This behavior, he looks upon as only the last step in the process we have described: a process with a wrong course through political powerlessness in an environment of globalized and an increasingly uncoordinated world.

Justice as a cultural matter, and the fact that the citizens believe the government as the guarantee for democracy, is neglected. Rajan points out that for every single dollar in salary growth between 1976 and 200758 percent of that growth went to the 1 percent constituting the richest families in USA. He continues to tell us that the income of the social middleclass and the poor labor class has stagnated or decreased, while the income of the richest 10 percent increased enormously. This development created a sort of disorder neglected by the politicians, but obviously disturbed the legitimacy of the politics. Rajan shows that this dilemma got politicians to compensate for the occurrence of inequality and the threat to their legitimacy, by voting forward liberalization of the credit market and favoring consume financed by loan. He writes that politicians - always sensible to their electorate - are choosing what they think as a solution of universal impact, namely to secure cheap loans to people which were suffering for not having got their share in the growth of the economy and its outcome. The banks took advantage of the situation to earn money of suspect real estate loans, namely subprime loans. The real estate market was for a while a hot spot in its function, realizing products to constantly higher prices. People bought housing products characterized by steadily rising prices, believing that the prices would continue to rise - into heaven. High risk was taken in this unregulated financial game. When the US Federal Reserve Bank let the interest on loan rise a bit, more and more people were not able to upkeep their loans, i.e. pay part payments and interest rates. Accordingly, the banks were shaken and threatened by imminent bankruptcy and some indeed went bankrupt. The financial crisis spread worldwide after 2007/2008.

The crisis that concerns the USA, EU and other Western countries is today what we might call a combination crisis, linked to both public and privatized loan and national budget deficits, for example, in Greek, Spain and 
Portugal. To get through this crisis the governments of these countries insist on budget cuts and saving programs, and cuts in salaries and pension arrangements. The impact of these actions is reduced market demand which boosts the crisis in terms of rising unemployment. A natural consequence of this is social and political disturbance visible in many European countries. Wolfgang Streeck (2012) writes: "The crisis of today threatens the democratic order as much as the economic order, maybe even more." As in the past, the crisis will find a provisional solution. Most likely the combination crisis this time will not favor the interests of speculative financial actors, which probably will become under control of stronger international regulations. The interests will remain, but expand themselves in tight contact with the real capital, i.e. in contact with global industrial monopoly interests. Consequently, the citizens will, to an even lower extent, look upon their government and politicians as representatives and guarantee for democracy.

\section{The democratic capitalism and the neo-Keynesian explanation of the combination crisis}

Governmental investments - and financial decision-making to regulate the effective demand in national economies is based on the basic principles introduced by John Maynard Keynes in his General Theory of Employment, Interest and Money. An explanation of the temporary crisis of the democratic capitalism linked to the Keynesian tradition must contain the following factors:

First, a central point in Keynesian theory was the argument for an active state whose main role was correcting markets and stabilizing economic circulations. I have described and analyzed the stagflation crisis of the $1970 \mathrm{~s} / 80 \mathrm{~s}$ and found that the state had remained active. The Western governments chose comprehensive public loan-taking and the issuing of government bonds, which later led to a public credit crisis.

Second, by using the term "inclination" to consume, Keynes was able to explain how the consuming behavior changed its character parallel to changing prices in the market - in our case in the housing market. When the pricing of real estate rises, an inclination rises, which generates a feeling of value gain, which turns into a sense of saving money. Further on, this turns into increasing consuming because it is believed that the "savings" are available right there. This is the background for the development of what we have called the privatized credit crisis as a follower of the public credit crisis. The Government liberalized the financial markets, and the inclination to finance consume by loans increased. The inclination was mostly created and inspired by the rising prices in the housing market, and the false feeling of thereby saving money. When the housing bubble cracked, it became clear that the saving was not real. 
Third, Keynes argued that financial melting down and the crack of aggregated demand in the economy was closely related to upcoming inequality of income and stagnation in salary payments. The government compensated by liberalization of the financial policy and expanded its loan reserves in order to keep the welfare state going by redressing social problems with arrangements of support, guarantees and access to privatized loans. What we call the combination crisis may be explained by this kind of Keynesian argumentation. While the net salary of 90 percent of the population changed very little during the last 20 years, the housing prices have grown enormously in the same period. It is this reality that Rajan's 'Fault Lines' describes and analyzes. It is all about this. Selling real estate gave a surplus which generated an inclination to higher consume in this market. Public and privatized crises of credit became combined; public loan taking to pay welfare was followed by a privatized crisis of credit. The EURO zone of the European Union (EU) was hit by a crisis as a follower of the financial crisis. The EU, the European Central Bank (ECB) and the International Monetary Fund (IMF) chose a strategy to press national governments to cut welfare arrangements to prevent states from going bankrupt; examples include countries like Greece, Spain, Portugal, Italy, Hungary and others. The privatized inclination to loan-taking was stopped by claiming a higher level of guarantee to get such loans.

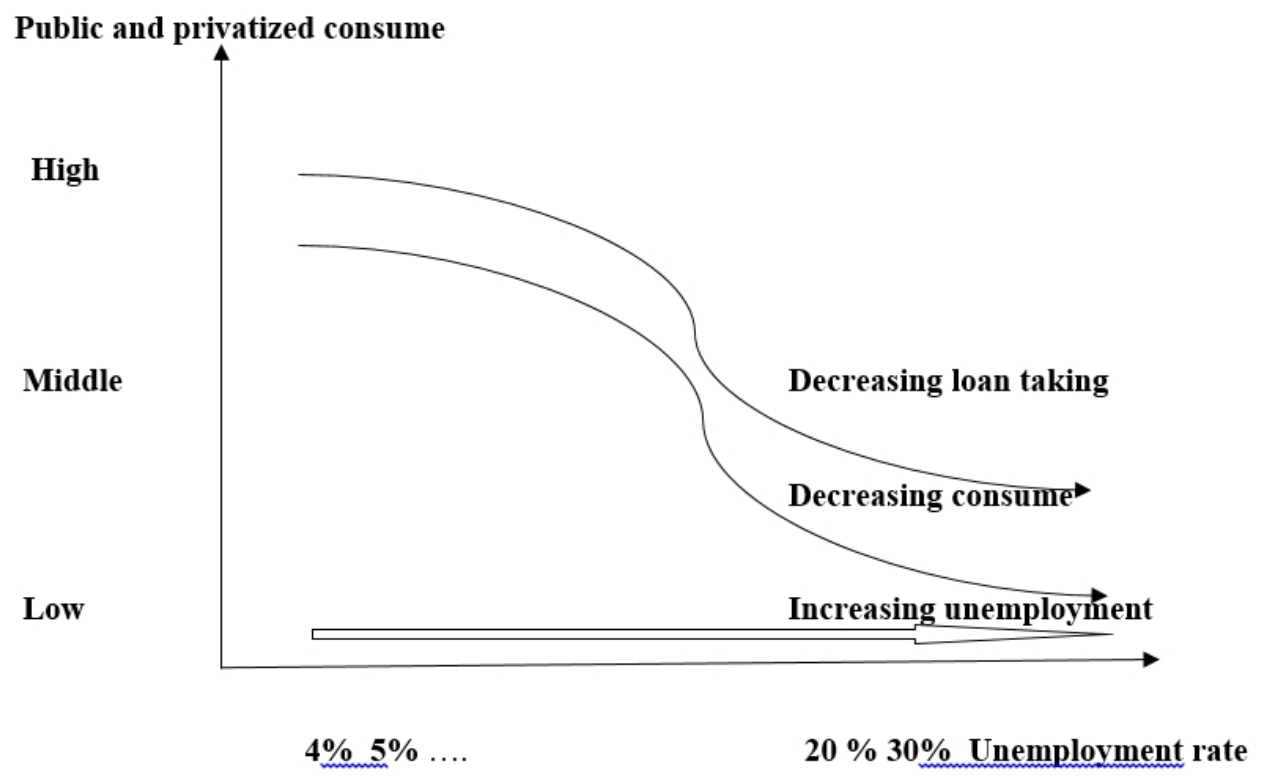

Figure 2. Correlation between three variables: decreasing loan taking and decreasing consuming implies increasing unemployment.

Fig. 2 intends to describe the situation characterizing the Western democratic capitalism of today, involving three variables. High level of loantaking and aggregated consume generated a situation of low employment. 
During the combination crisis of public and privatized credit, the unemployment rate will increase as time pass on. By necessity, the inclination to public and private consuming will be shrinking due to mutual dependency between the variables. The inclination to the crack-down of aggregated demand and the growth of unemployment is strengthening by firm budget regulations and pay back of public loans. This is the situation that occurred in the Euro-zone countries and hit them both economically and politically. In terms of Keynesian theory, the effective demand will decrease in the national economies. This triggers a negative economic spiral with growing unemployment followed by a corresponding decrease in purchasing power. When the GNP begins decreasing it triggers printing of money, and the economy gets threatened by increasing inflation. In the EU the European Central Bank (ECB) is very much aware of this mechanism, and keeps on implementing a strong monetary policy in the Euro-zone. The other side of the coin is the grave impact of this policy on the Mediterranean countries already hit by the crisis of the capitalism. In the Euro-zone no member state is allowed to devaluate its currency (Euro) in their endeavor to win more competitive ability in the world market. Low inflation rate keeps loans from falling in terms of nominal value. Consequently, the unemployment rate continues to rise, fig. 2, followed by social and political disorder in the European countries mentioned. The crisis is most likely spreading to other countries as well.

A temporary respond in Europe according to fig. 2 seems to be, on the one hand, to increase the effective demand by importing capital from outside Europe to compensate for internal public loan-taking. Such capital could come from the growing economies of the so-called BRICS countries, i.e. Brazil, Russia, India, China and South Africa. USA experiences a solution to the financial crisis by being a market for Chinese export whose payment remains as loan but with US dollar as involved currency in the business transactions. US dollars are printed and put into the money circulation, but inflation fails to appear because of US dollar being a global currency in economic transactions.

On the employment side, decreasing consuming might be avoided by increase the salaries of the labor force.. Increasing demand and consume will be an immediate output of the strategy - deduced from the Keynesian analyses of inclination. The understanding of the combination crisis in the democratic capitalism is detained with a failure when it is explained as a crisis caused by an expensive welfare state together with public loans taken up to restore and pay for the services of the welfare state. Also, the consideration of making the financial crisis part of the general housing policy and the political wish to make people owners of their own housing facilities is detained with failure (Mullard, 2011: 219). The explanation is rather to be found in the absence of 
Keynesian theory and its recommendation of governmental interventions when crisis hit the economic circulation in the capitalistic economy.

\section{Conclusion: Who governs?}

Shaping economic politics represents political choices. To go for a liberalized market economy, generates consequences very much different compared to those generated by Keynesian strategies. The Nobel Prize winner in economy, Paul Krugman, has named the period between 1950 and 1972 "the period of compression" (2007). The Keynesian principles dominated and pressed the market and the state together in a cooperative order. The unemployment was low and the inflation under control. Interventions of the government adjusted the market, and the building of the appreciated welfare state was the final outcome.

In contrast to this situation, Krugman said that the period since 1980 has been characterized by divergence; the state has withdrawn from the market and become a regulatory state, while the market forces were given freedom to develop and expand, only limited by, and in interplay with judicial regulations. Government was replaced with governance. The period is characterized by high unemployment, but with inflation under control. This control came up due to the monetary political strategy whose main objective was fighting inflation. The salaries of ordinary people in the democratic capitalist countries went into a race to the bottom, and the trade unions lost power and influence in the economic and political games. This form of governance under former Prime Minister Margaret Thatcher in the UK and former President Ronald Reagan in the USA is well known.

Since the 1980s fragmentation of government regimes has been a dominant development trend due to steering principles deduced from New Public Management theories. The representative democracy has become weak and fragmented and under control of international supranational governance structures like the EU. Therefore, citizens look upon governments not as representative for their own national interests, but as representatives for the interests of foreign states and international organizations. Out of this comes public poverty and confusion regarding who really governs.

\section{References:}

1. Cumes, J. W. C. (1984), The Recontruction of the World Economy, Melborne: Longman Cheshire.

2. Dahl, R.A. (1989), Democracy and its Critics. Yale: Yale University Press.

3. Europautredning (2012), Utenfor og innenfor, NOU 2012:2. Utenriksdepartementet, Oslo: Oslo dep. 
4. Friedman, M. (1962/1972), Capitalism \& Freedom. Chicago: The University of Chicago Press.

5. Keating, M. (1998), The new regionalism: Territorial restructuring and political change. Cheltenham, UK: Edward Elgar.

6. Keynes, J. M. (1936), General Theory of Employment, Interest and Money. London: Mavmillan.

7. Krugman, P. (2007), The Conscience of a Liberal. New York: W.W. Norton Company

8. Lane, J.E. og Ersson, S. (2003), Democracy: A comparative approach. London and New York: Routledge.

9. Majone, G. (1994), The rise of the regulatory state in Europe. West European Politics, 17 (3), 77-101.

10. Majone, G. (1997), From the positive to the regulatory state: causes and consequences of change in the mode of government. Journal of Public Policy, 17 (3), 139-89.

11. Majone, G. (2003), 'The Politics of Regulation and European Regulatory Institutions'. Op.cit. Hayward, J. and Menon, A. (eds.) (2003: 297-312).

12. Mullard, M. (2011), The Politics of Recession. Cheltenham, UK and Northampton, MA, US: Edward Elgar Publishing.

13. OECD (1977), Towards Full Employment and Price Stability. Paris: OECD.

14. Rajan, R. G. (2010), Fault Lines: How Hidden Fractures Still Threaten the World Economy. Princeton: Princeton University Press.

15. Scharpf, F. (1999), Governing in Europe: Effective and democratic? Oxford: Oxford University Press.

16. Stigler, G. (ed.) (1988), Chicago studies in political economy, Chicago: University of Chicago University Press.

17. Streeck, W. (2012), Gjeldens byrde., Le Monde Diplomatique (norsk utgave), Jan 2012.

18. Veggeland, N. (2009), Taming the regulatory state: Politics and ethics, Cheltenham, UK and Northampton, MA, US: Edward Elgar Publishing.

19. Veggeland, N. (2010), Den nye reguleringsstaten. Idébrytninger og styringskonflikter, Oslo: Gyldendal Akademisk.

20. Veggeland, N. (2012), Regulering og reguleringsparadokser, Trondheim: Akademisk forlag.

21. Weiler, J. H. (1999), The Constitution of Europe, Cambridge: Cambridge University Press. 